ORIGINAL ARTICLE

\title{
PREVALENCE OF AND FACTORS ASSOCIATED WITH INCREASED SUICIDE RISK AMONG CHRONIC NON-CANCER PAIN PATIENTS IN ZAGAZIG UNIVERSITY HOSPITALS
}

\author{
Mohamed Abdelghani Moustafa, Yasser Mohamed Raya, Rafik Reda Abdellatif, Kariman \\ Rabie Mohamed \\ Psychiatry Department, Faculty of Medicine, Zagazig University, Zagazig, Egypt
}

\begin{abstract}
*Corresponding Author:
Kariman Rabie Mohamed

Psychiatry Department, Faculty

of Medicine, Zagazig

University, Zagazig, Egypt
\end{abstract}

okirabie91@gmail.com

Submit Date 2019-03-17

Revise Date 2019-04-15

Accept Date 2019-04-22

\begin{abstract}
Background: chronic non-cancer pain $(\mathrm{CNCP})$ patients are more likely to experience suicidal ideation and behaviors compared to the general population. To our knowledge, this is the first study in Egypt discussing the prevalence and risk factors of suicide among CNCP patients. Objectives of this study aimed to identify the most important general and pain-related risk factors of suicide in patients with chronic non-cancer pain at Zagagzig University Hospitals. Methods: a total of 179 patients with chronic noncancer pain were recruited from Outpatient clinics, Zagazig University hospitals, Sharkia. A simple questionnaire was structured for all participants to collect data onsocio-demographic data and pain-related (intensity, duration, interference, sleep problems). Psychometric assessment was done which included; the Visual Analogue Scale (VAS), Structured Clinical Interview for DSM-IV-TR Axis I Disorders (SCID-I) and Columbia Scale for the Rating of Suicide Severity(C-SSRS).Results: approximately half of the patients $(48.6 \%)$ reported lifetime suicidal ideation and only $1.1 \%$ reported life time suicide attempts, Suicidal ideation occurred after onset of pain in $26.3 \%$ of the participants. Several risk factors for SI in chronic pain were identified, including younger age, previous substance abuse, past history of psychiatric illness and sleep-onset insomnia.

Conclusion: results of this study are consistent with the prevailing literature on pain and suicide demonstrating a high prevalence of suicidal ideation in the chronic pain population. Novel predictive variables were also identified that will provide the basis for developing a risk stratification model that can be further tested prospectively in chronic pain patients.

KEYWORDS: chronic non-cancer pain, suicide, Zagazig, Egypt.
\end{abstract}

\section{INTRODUCTION}

$\mathrm{S}_{\mathrm{w}}$ uicide is the 17th leading cause of death worldwide, accounting for at least $1.4 \%$ of all deaths in 2015 [1].Suicide is more specifically classified into three categories: suicidal ideation, suicide plan and suicide attempt [2].

According to International Association for the Study of Pain (IASP), pain is defined as an "unpleasant sensory and emotional experience associated with real or potential tissue injury or damage" [3]. This experience as perceived by the subject is complex, affecting all dimensions (emotional, cognitive, physical, spiritual, work, family, and Social life) [4].

Chronic pain has been recognized as pain that lasts for more than one month beyond the normal course of recovery, is associated with a chronic disease process, or reappears at intervals of months or years) [5]. Usually pain 
is regarded as chronic when it lasts or recurs for more than 3 to 6 months [6].

People with chronic non-cancer pain (CNCP) have almost double the risk of death by suicide and are 2 to 3 times more likely to experience suicidal ideation or make attempts Compared to those without $\mathrm{CNCP}$ [7].Furthermore, approximately two-thirds of those who had attempted suicide had a history of chronic pain [8].

The World Health Organization has recognized the importance of $\mathrm{CNCP}$ as a risk factor for suicide and has recommended that any individual over 10 years of age who presents a CNCP condition should be assessed with respect to potential suicidal behaviors and has acknowledged chronic pain as an individual key risk factor for suicide [9].Up to our knowledge, there is a few data, if any, about suicide risk among chronic non-cancer pain patients at Zagagzig University Hospitals so the aim of study was to assess the prevalence of suicide among CNCP patients and to identify the factors associated with increased suicide risk.

\section{METHODS}

The work has been carried out in accordance with The Code of Ethics of the World Medical Association (Declaration of Helsinki) for studies involving humans. A simple randomized cross sectional study was done and sample of 179 chronic pain patients not 2ry to malignancy. Sample was calculated to be 179 chronic non-cancer pain patients, using open Epi x program, at $80 \%$ power of study, $95 \%$ confidence interval, as the total number of chronic pain patients attending to out-patients clinics is 720 in 6 months. .Recruitment was conducted between 1 February 2018 and 30 August 2018. Patients included were from both sexes, in the age group from18-65 years old, were recruited from various out-patient clinics, Zagazig University hospitals, Sharkia, We excluded patients with any current psychiatric disorders, mental retardation, substance abuse and refusal of participation. Ethical committee approval and a written informed consent were obtained. A questionnaire pertaining to their socioeconomic status\& clinical, history was administered.

The Psychometric assessments that were done by a psychiatrist were:

The Visual Analogue Scale (VAS) [10] to evaluate pain intensity. The visual analogue scale (VAS) is a simple and frequently used method for the assessment of variations in intensity of pain. (VAS) is most commonly a straight $100-\mathrm{mm}(10 \mathrm{~cm})$ line, that has the words "no pain" at the left-most end and "worst pain imaginable" at the right-most end .Patients are instructed to place a mark on the line indicating the amount of pain that they feel at the time of the evaluation. VAS scores $\leqslant 3.4 \mathrm{~cm}$ were best described as mild pain, $3.5 \mathrm{~cm}$ to $7.4 \mathrm{~cm}$ as moderate pain, and $\geqslant 7.5 \mathrm{~cm}$ as severe pain [11].

The Structured Clinical Interview for DSMIV-TR Axis I Disorders (SCID-I) [12] To exclude current psychiatric Axis I disorders. It is a semi-structured interview guide that is designed to enable a clinician or a trained mental health professional to make DSM-IVTR Axis I diagnoses The basic procedure involved the interviewer reading the SCID questions to the subject in sequence and the goal being to elicit the necessary information to allow the interviewer to decide whether the individual DSM-IV criterion is met.

The standard SCID-I (known as the "Research Version") covers most of the major DSM-IV Axis I disorders, including mood disorders, psychotic disorders, substance use disorders, anxiety disorders, somatoform disorders, eating disorders, and adjustment disorders. For many disorders, questions were also provided to allow for the rating of various subtypes and specifiers.

Columbia Scale for the Rating of Suicide Severity(C-SSRS) [13] to evaluate patient's suicidal behavior. A relatively brief, structured interview-based instrument with good validity and internal reliability, the version of the CSSRS used in this study assessed suicidal ideation in the last visit, before \& after pain and 
suicidal behaviors for lifetime. The SI severity scale is composed of five yes=no questions of increasingly severe suicidal thoughts: a wish to be dead (1), non-specific suicidal thoughts (2), suicidal thoughts with a method (3), suicidal intent without specific plan (4), and suicidal intent with specific plan (5). This scale was scored from 0 to 5 according to the most severe suicidal ideation endorsed The C-SSRS suicidal ideation intensity subscale (SI intensity. in form of five items (frequency, duration, controllability, deterrents, reasons for ideation) that are scored from 1 to 5 and summed for the total SI intensity score. . Suicidal behaviors were assessed dichotomously (yes=no) and include actual suicide attempts, interrupted suicide attempts, aborted suicide attempts, other preparatory acts The C-SSRS had been validated for use with clinical adolescent and adult populations and demonstrated strong psychometric properties [13].

\section{Collection of socio-demographic and clinical data}

For CNCP patients by a semi-structured questionnaire specifically developed for this study (age, sex, work status, residence, marital status, family type, educational level, social class and special habits). Pain analysis data (sites, onset, course, duration, severity and treatment), Past history of psychiatric and substance related disorders and family history of suicide ideation and/or attempt as well as psychiatric disorders.

\section{Statistical analysis}

Data analysis was performed using the software SPSS (Statistical Package for the Social Sciences) version 18. Quantitative variables were described using their means and standard deviations. Qualitative data were represented as frequencies and relative percentages .Chi square test was used to calculate difference between qualitative variables in different groups.Quantitative data were expressed as mean \pm SD (Standard deviation). Independent $\mathrm{T}$ test was used to calculate difference between quantitative variables in 2 groups in normally distributed data. Mann Whiteny test was used to calculate differences between qualitative variables in 2 groups in not normally distributed data. Pearson correlation coefficient used to calculate correlation between quantitative variables .

We consider (+) sign as indication for direct correlation i.e. increase frequency of independent lead to increase frequency of dependent \& (-) sign as indication for inverse correlation i.e. increase frequency of independent lead to decrease frequency of dependent, also we consider values near to 1 as strong correlation \& values near 0 as weak correlation. The level of statistical significance(S) was set at $5 \%(\mathrm{P}<0.05)$, highly significant difference was present if $\mathrm{p} \leq 0.001$ (HS) and p-value $\geq 0.05$ was considered statistically insignificant(NS).

\section{RESULTS}

The study included 179 CNCP patients with a mean age 44.16, (56\%) female, (74.3\%) married, (41\%) housewives, $(35.8 \%)$ moderately educated, urban residents represent (58\%), (50.3\%) lived with nuclear family, $(55 \%)$ had low social class and (22.3\%) were smoker [Table1].Ten percent had past history of substances abuse and psychiatric disease while $(49.7 \%)$ had disturbed sleep [Table2]. A bout $80.4 \%$ of the studied group had gradual onset pain also $49.7 \%$ had progressive pain while $58.7 \%$ had severe pain. In $85.5 \%$ of the patients the pain is due to disease and in $78.2 \%$ the pain were musculoskeletal. The pain was poly site in $67 \%$ of the patients and most frequent sites were back, Knee and cervical (46.4\%, $33 \%$ and $28.5 \%$ respectively) [Table3].

Our study found $48.6 \%$ of the studied group reported C-SSRS based suicidal ideation [figure 1] and only $1.1 \%$ reported life time suicide attempts. SI was reported in $10 \%$ of patients before the onset of pain while suicidal ideation occurred after onset of pain in $26.3 \%$ of the participants; 
There were statistically significant differences between younger age, previous substance abuse, past history of psychiatric illness, and sleep-onset insomnia and increased suicide risk in $\mathrm{CNCP}$ patients [Table4\&5].

\section{Suicidal ideation}

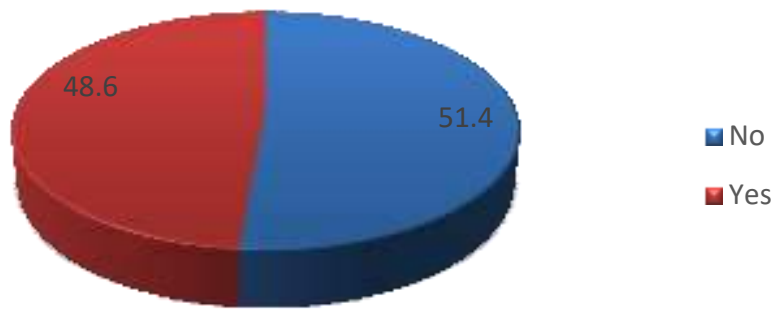

Figure (1) Frequency of suicidal ideation among the studied group

Table 1.Demographic data of the studied group:

\begin{tabular}{|c|c|c|c|}
\hline \multicolumn{2}{|c|}{ Variable } & \multirow{2}{*}{\multicolumn{2}{|c|}{$\begin{array}{c}(n=179) \\
44.16 \pm 12.60 \\
19-65\end{array}$}} \\
\hline Age : (year) & $\begin{array}{l}\text { Mean } \pm S D \\
\text { Range }\end{array}$ & & \\
\hline \multicolumn{2}{|c|}{ Variable } & No & $\%$ \\
\hline Sex: & $\begin{array}{l}\text { Female } \\
\text { Male }\end{array}$ & $\begin{array}{c}100 \\
79\end{array}$ & $\begin{array}{l}55.9 \\
44.1\end{array}$ \\
\hline Resident: & $\begin{array}{l}\text { Rural } \\
\text { Urban }\end{array}$ & $\begin{array}{c}75 \\
104\end{array}$ & $\begin{array}{l}41.9 \\
58.1\end{array}$ \\
\hline Education: & $\begin{array}{l}\text { Illiterate } \\
\text { Low education } \\
\text { Moderate education } \\
\text { High education }\end{array}$ & $\begin{array}{l}49 \\
32 \\
64 \\
34\end{array}$ & $\begin{array}{c}27.4 \\
17.9 \\
35.8 \\
19\end{array}$ \\
\hline Occupation: & $\begin{array}{l}\text { House wife } \\
\text { Skilled } \\
\text { Employee } \\
\text { Retired } \\
\text { Not working } \\
\text { Specialist }\end{array}$ & $\begin{array}{c}73 \\
49 \\
12 \\
15 \\
1 \\
29\end{array}$ & $\begin{array}{c}40.8 \\
27.4 \\
6.7 \\
8.4 \\
0.6 \\
16.2\end{array}$ \\
\hline Marital status: & $\begin{array}{l}\text { Single } \\
\text { Married } \\
\text { Widow } \\
\text { Divorced }\end{array}$ & $\begin{array}{c}24 \\
133 \\
12 \\
10\end{array}$ & $\begin{array}{l}13.4 \\
74.3 \\
6.7 \\
5.6\end{array}$ \\
\hline Family type: & $\begin{array}{l}\text { Joint } \\
\text { Nuclear }\end{array}$ & $\begin{array}{l}89 \\
90\end{array}$ & $\begin{array}{l}49.7 \\
50.3\end{array}$ \\
\hline Smoking & $\begin{array}{l}\text { Yes } \\
\text { No }\end{array}$ & $\begin{array}{c}40 \\
139\end{array}$ & $\begin{array}{l}22.3 \\
77.7\end{array}$ \\
\hline Social class: & $\begin{array}{l}\text { Very low \& Low } \\
\text { Moderate } \\
\text { High }\end{array}$ & $\begin{array}{c}102 \\
64 \\
13\end{array}$ & $\begin{array}{c}56.9 \\
35.8 \\
7.3\end{array}$ \\
\hline
\end{tabular}


Table 2.Personal and family History among the studied group:

\begin{tabular}{|l|l|c|c|}
\hline \multicolumn{1}{c|}{$\begin{array}{c}\text { Variable } \\
\text { Other physical illness: }\end{array}$} & \multicolumn{2}{c|}{$(\mathbf{n = 1 7 9})$} \\
\hline & No & No & $\%$ \\
\hline Past history of psychiatric disease: & Yes (DM \& HPT) & 127 & 70.9 \\
& No & 52 & 29.1 \\
\hline Previous substance abuse & Yes & 161 & 89.9 \\
& No & 18 & 10.1 \\
\hline Family history: & yes & 161 & 89.9 \\
& Psychiatric disease: & 18 & 10.1 \\
\hline & No & 166 & \\
& Yes & 13 & 92.7 \\
& Suicide: & & 7.3 \\
\hline Sleep: & No & 177 & 98.9 \\
& Yes & 2 & 1.1 \\
\hline
\end{tabular}

Table 3.Pain analysis data among the studied group:

\begin{tabular}{|c|c|c|c|}
\hline \multicolumn{2}{|r|}{ Variable } & \multicolumn{2}{|c|}{$(n=179)$} \\
\hline & & No & $\%$ \\
\hline Onset & $\begin{array}{l}\text { Acute } \\
\text { Gradual }\end{array}$ & $\begin{array}{c}35 \\
144\end{array}$ & $\begin{array}{l}19.6 \\
80.4\end{array}$ \\
\hline Course: & $\begin{array}{l}\text { Stationary } \\
\text { Remission \&exacerbation } \\
\text { Progressive } \\
\text { Regression }\end{array}$ & $\begin{array}{c}4 \\
80 \\
89 \\
6\end{array}$ & $\begin{array}{c}2.2 \\
44.7 \\
49.7 \\
3.4\end{array}$ \\
\hline $\begin{array}{l}\text { Duration: } \\
\text { (Years) }\end{array}$ & $\begin{array}{l}\text { Mean } \pm S D \\
\text { Median (Range) }\end{array}$ & \multicolumn{2}{|c|}{$\begin{array}{l}4.95 \pm 5.18 \\
3(0.1-30)\end{array}$} \\
\hline \multirow[t]{2}{*}{ Severity: } & $\begin{array}{l}\text { Mean } \pm S D \\
\text { Median (Range) }\end{array}$ & \multicolumn{2}{|c|}{$\begin{array}{l}6.7 \pm 1.9 \\
7(2-10)\end{array}$} \\
\hline & $\begin{array}{l}\text { Mild } \\
\text { Moderate } \\
\text { Sever }\end{array}$ & $\begin{array}{c}13 \\
61 \\
105\end{array}$ & $\begin{array}{l}7.3 \\
34.1 \\
58.7\end{array}$ \\
\hline Cause: & $\begin{array}{l}\text { Disease } \\
\text { Trauma } \\
\text { Unknown }\end{array}$ & $\begin{array}{c}153 \\
21 \\
5\end{array}$ & $\begin{array}{l}85.5 \\
11.7 \\
2.8\end{array}$ \\
\hline Type: & $\begin{array}{l}\text { Musculoskeletal(back-knee-cervical) } \\
\text { Vascular(headache-ischemic) } \\
\text { Neuropathic }\end{array}$ & $\begin{array}{c}140 \\
21 \\
18\end{array}$ & $\begin{array}{l}78.2 \\
11.7 \\
10.1\end{array}$ \\
\hline Site: & $\begin{array}{l}\text { Mono site } \\
\text { Poly site }\end{array}$ & $\begin{array}{c}59 \\
120\end{array}$ & $\begin{array}{l}33 \\
67\end{array}$ \\
\hline
\end{tabular}




\begin{tabular}{|l|l|c|c|}
\hline & Back & 83 & 46.4 \\
& Knee & 59 & 33 \\
& Cervical & 51 & 28.5 \\
& Headache & 21 & 11.7 \\
& Heel & 10 & 5.6 \\
& Wrist & 20 & 11.2 \\
\hline \multirow{2}{*}{ Referred pain } & Extremities & 36 & 20.1 \\
& No & 137 & 76.5 \\
\hline
\end{tabular}

Sd: Standard deviation

Table 4.Relation between increased suicide risk and socio-demographic data among the studied group:

\begin{tabular}{|c|c|c|c|c|c|c|c|}
\hline \multicolumn{2}{|c|}{ Variable } & \multirow{2}{*}{\multicolumn{2}{|c|}{$\begin{array}{l}\text { No suicide } \\
\qquad \begin{array}{c}(n=92) \\
47 \pm 13.23 \\
19-65\end{array}\end{array}$}} & \multirow{2}{*}{\multicolumn{2}{|c|}{$\begin{array}{c}\begin{array}{c}\text { Suicide } \\
(\mathrm{n}=\mathbf{8 7})\end{array} \\
\begin{array}{c}41.16 \pm 11.21 \\
21-65\end{array}\end{array}$}} & \multirow{3}{*}{$\begin{array}{c}\mathrm{T} \\
3.18 \\
\chi^{2}\end{array}$} & \multirow{3}{*}{$\begin{array}{c}\mathbf{P} \\
\mathbf{0 . 0 0 2} \\
* * \\
\mathbf{P}\end{array}$} \\
\hline Age : (year) & $\begin{array}{l}\text { Mean } \pm S D \\
\text { Range }\end{array}$ & & & & & & \\
\hline \multicolumn{2}{|r|}{ Variable } & No & $\%$ & No & $\%$ & & \\
\hline Sex: & $\begin{array}{l}\text { Female } \\
\text { Male }\end{array}$ & $\begin{array}{l}51 \\
41\end{array}$ & $\begin{array}{l}55.4 \\
44.6\end{array}$ & $\begin{array}{l}49 \\
38\end{array}$ & $\begin{array}{l}56.3 \\
43.7\end{array}$ & 0.01 & $\begin{array}{c}0.91 \\
\mathrm{NS}\end{array}$ \\
\hline Resident: & $\begin{array}{l}\text { Rural } \\
\text { Urban }\end{array}$ & $\begin{array}{l}39 \\
53\end{array}$ & $\begin{array}{l}42.4 \\
57.6\end{array}$ & $\begin{array}{l}36 \\
51\end{array}$ & $\begin{array}{l}41.4 \\
58.6\end{array}$ & 0.02 & $\begin{array}{c}0.89 \\
\text { NS }\end{array}$ \\
\hline Education: & $\begin{array}{l}\text { Illiterate } \\
\text { Low education } \\
\text { Moderate education } \\
\text { High education }\end{array}$ & $\begin{array}{l}29 \\
12 \\
31 \\
20\end{array}$ & $\begin{array}{c}31.5 \\
13 \\
33.7 \\
21.7\end{array}$ & $\begin{array}{l}20 \\
20 \\
33 \\
14\end{array}$ & $\begin{array}{c}23 \\
23 \\
37.9 \\
16.1\end{array}$ & 4.64 & $\begin{array}{c}0.20 \\
\mathrm{NS}\end{array}$ \\
\hline Occupation: & $\begin{array}{l}\text { House wife } \\
\text { Skilled } \\
\text { Employee } \\
\text { Retired } \\
\text { Not working } \\
\text { Specialist }\end{array}$ & $\begin{array}{c}37 \\
23 \\
7 \\
10 \\
1 \\
14\end{array}$ & $\begin{array}{c}40.2 \\
25 \\
7.6 \\
10.9 \\
1.1 \\
15.2\end{array}$ & $\begin{array}{c}36 \\
26 \\
5 \\
5 \\
0 \\
15\end{array}$ & $\begin{array}{c}41.4 \\
29.9 \\
5.7 \\
5.7 \\
0 \\
17.2\end{array}$ & 3.10 & $\begin{array}{c}0.69 \\
\mathrm{NS}\end{array}$ \\
\hline $\begin{array}{l}\text { Marital } \\
\text { status: }\end{array}$ & $\begin{array}{l}\text { Single } \\
\text { Married } \\
\text { Widow } \\
\text { Divorced }\end{array}$ & $\begin{array}{c}12 \\
68 \\
6 \\
6\end{array}$ & $\begin{array}{c}13.1 \\
73.9 \\
6.5 \\
6.5\end{array}$ & $\begin{array}{c}12 \\
65 \\
6 \\
4\end{array}$ & $\begin{array}{c}13.8 \\
74.7 \\
6.8 \\
4.6\end{array}$ & 0.33 & $\begin{array}{l}0.96 \\
\mathrm{NS}\end{array}$ \\
\hline Family type: & $\begin{array}{l}\text { Joint } \\
\text { Nuclear }\end{array}$ & $\begin{array}{l}51 \\
41\end{array}$ & $\begin{array}{l}55.4 \\
44.6\end{array}$ & $\begin{array}{l}37 \\
49\end{array}$ & $\begin{array}{l}43 \\
57\end{array}$ & 2.38 & $\begin{array}{l}0.10 \\
\text { NS }\end{array}$ \\
\hline Smoking & $\begin{array}{l}\text { No } \\
\text { Yes }\end{array}$ & $\begin{array}{l}76 \\
16\end{array}$ & $\begin{array}{l}82.6 \\
17.4\end{array}$ & $\begin{array}{l}63 \\
24\end{array}$ & $\begin{array}{l}72.4 \\
27.6\end{array}$ & 2.68 & $\begin{array}{l}0.10 \\
\text { NS }\end{array}$ \\
\hline Social class: & $\begin{array}{l}\text { Very low \& Low } \\
\text { Moderate } \\
\text { High }\end{array}$ & $\begin{array}{c}54 \\
32 \\
6\end{array}$ & $\begin{array}{c}58.7 \\
34.8 \\
6.5\end{array}$ & $\begin{array}{c}48 \\
32 \\
7\end{array}$ & $\begin{array}{c}55.2 \\
36.8 \\
8\end{array}$ & 0.29 & $\begin{array}{c}0.87 \\
\mathrm{NS}\end{array}$ \\
\hline
\end{tabular}

$\mathrm{Sd}$ : Standard deviation $\quad \mathrm{t}$ : Independent t test NS: Non significant $(P>0.05) \quad * *$ : Highly significant $(P<0.01)$ 
Table 5.Relation between increased suicide risk \& personal and family History among the studied group:

\begin{tabular}{|c|c|c|c|c|c|c|c|}
\hline & Variable & & $\begin{array}{l}\text { cide } \\
\text { 2) }\end{array}$ & & & $x^{2}$ & $\mathbf{P}$ \\
\hline & & No & $\%$ & No & $\%$ & & \\
\hline $\begin{array}{l}\text { Previous } \\
\text { substance } \\
\text { abuse: }\end{array}$ & $\begin{array}{l}\text { No } \\
\text { Yes }\end{array}$ & $\begin{array}{c}87 \\
5\end{array}$ & $\begin{array}{c}94.6 \\
5.4\end{array}$ & $\begin{array}{l}74 \\
13\end{array}$ & $\begin{array}{l}85.1 \\
14.9\end{array}$ & 4.47 & $0.04 *$ \\
\hline $\begin{array}{l}\text { Other } \\
\text { physical } \\
\text { illness: }\end{array}$ & $\begin{array}{l}\text { No } \\
\text { Yes (DM \& HPT) }\end{array}$ & $\begin{array}{l}66 \\
26\end{array}$ & $\begin{array}{l}71.7 \\
28.3\end{array}$ & $\begin{array}{l}61 \\
26\end{array}$ & $\begin{array}{l}70.1 \\
29.9\end{array}$ & 0.06 & $\begin{array}{l}0.81 \\
\mathrm{NS}\end{array}$ \\
\hline $\begin{array}{l}\text { Past history } \\
\text { of } \\
\text { psychiatric } \\
\text { disease: }\end{array}$ & $\begin{array}{l}\text { No } \\
\text { Yes }\end{array}$ & $\begin{array}{c}89 \\
3\end{array}$ & $\begin{array}{c}96.7 \\
3.3\end{array}$ & $\begin{array}{l}72 \\
15\end{array}$ & $\begin{array}{l}82.8 \\
17.2\end{array}$ & 9.66 & $\begin{array}{c}\mathbf{0 . 0 0 2} \\
* *\end{array}$ \\
\hline $\begin{array}{l}\text { Family } \\
\text { history: }\end{array}$ & $\begin{array}{l}\text { Psychiatric disease: } \\
\text { No } \\
\text { Yes } \\
\text { Suicide: } \\
\text { No } \\
\text { Yes }\end{array}$ & $\begin{array}{c}86 \\
6 \\
92 \\
2\end{array}$ & $\begin{array}{c}93.5 \\
6.5 \\
100 \\
0\end{array}$ & $\begin{array}{c}80 \\
7 \\
85 \\
2\end{array}$ & $\begin{array}{c}92 \\
8 \\
97.7 \\
2.3\end{array}$ & 0.15 & $\begin{array}{c}0.70 \\
\text { NS } \\
0.14 \\
\text { NS }\end{array}$ \\
\hline Sleep: & $\begin{array}{l}\text { Normal } \\
\text { Disturbed } \\
\text { Initial insomnia }\end{array}$ & $\begin{array}{l}27 \\
46 \\
19\end{array}$ & $\begin{array}{c}29.3 \\
50 \\
20.7\end{array}$ & $\begin{array}{l}14 \\
43 \\
30\end{array}$ & $\begin{array}{l}16.1 \\
49.4 \\
34.5\end{array}$ & 6.56 & $0.04 *$ \\
\hline $\begin{array}{l}\chi^{2}: \text { Chi squa } \\
*: \text { Significan }\end{array}$ & $\begin{array}{l}\text { test } \\
(\mathbf{P}<0.05)\end{array}$ & $\begin{array}{l}\text { on } \\
\text { ghl }\end{array}$ & $\begin{array}{l}\text { fican } \\
\text { nifica }\end{array}$ & $\begin{array}{l}0.0 \\
P<0\end{array}$ & & & \\
\hline
\end{tabular}

\section{DISCUSSION}

People with CNCP are 2 to 3 times more likely to experience suicidal ideation or die by suicide [7]. A narrative review has confirmed the relationships between $\mathrm{CNCP}$ and increased risk of presence for all three suicidal variables [14]. Furthermore; approximately two-thirds of those who had attempted suicide had a history of chronic pain [8]. The World Health Organization (WHO) has acknowledged chronic pain as an individual key risk factor for suicide $[9,15]$.

This study conducted on $179 \mathrm{CNCP}$ patients were recruited from various out-patient clinics, Zagazig University Hospitals, Sharkia, Egypt, From February to October, 2018.

In the current study, approximately half of the patients $(48.6 \%)$ reported lifetime suicidal ideation and only, $1.1 \%$ reported lifetime suicide attempts, which are consistent with a study [16] which found that about $46 \%$ of chronic pain patients experienced lifetime suicidal ideation. Furthermore, according to another study [17] the prevalence of SI in chronic pain patients was $41 \%$. Other research [7] who found the prevalence of lifetime suicidal ideation in chronic pain patients ranges from $5.2 \%$ to $50 \%$.

These high rates of suicidal behaviors in people with CNCP were explained by Joiner's Interpersonal Theory of suicide (IPT) which proposed that perceived burdensomeness and low belongingness were associated with suicidal desire, whereas the capability to act on the desire was acquired over time [18]. The impact of chronic pain on an individual's employment, physical functioning, and quality of life, and the reliance on others that was prevalent in this population provided a plausible explanation of the high levels of 
suicidal desire in this group [19]. Besides, many people live with $\mathrm{CNCP}$ for a number of years and often fail to receive complete relief for their pain through medications or other treatments. The issue that may explain why some CNCP develop the capability to act on this suicidal desire over time [8].

Despite the high frequency of suicidal ideation in our study, suicide attempts were quite low. This may be attributed to being in Egypt where feelings of hopelessness and the intention to kill oneself are not common, and the individuals who lost hope in relief by God and self-inflicted death were blasphemous and punishable in the afterlife [20]. Moreover, the relation between the time of appearance of SI and the onset of pain was notably crucial. Our study found that SI was reported in $10 \%$ of patients before the onset of pain while approximately $27 \%$ of patients claimed that the experienced SI following the appearance of pain. These findings were inconsistent with a study[16] where SI occurred after the onset of pain in $36.5 \%$ of the sample, and $10.0 \%$ of the sample experienced ideation before their pain condition. These results would reflect the robust association and the direct impact of the presence of pain on the increased suicide risk among these individuals.

Different studies [19,21] having examined demographic factors associated with SI in individuals with CNCP found no support for a relationship with sex, age, marital status, education level or work status. Our study found increased suicidal risk is associated with younger age with no associations with other socio-demographic characteristics. This was consistent with other studies [22, 23]. The close association between increased suicide risk and younger age in our study can be explained as younger age suffers more from life stresses, adjustment difficulties and increasing responsibilities that cannot tolerate beside pain burden.

Current study found significant correlation between increased suicide risk and patients with previous history of substance abuse. This finding is supported by a study [24] who reported that history of substance abuse had a relative contribution on previous suicide attempt, but not on current suicidal intent. It is plausible that these patients used drugs as a passive method of managing the pain, instead of using more active coping strategies such as diverting attention from the pain or reinterpreting the pain sensation.

Several studies [24, 25, 26], have examined the link between psychological factors and suicidality in chronic pain patients. In our study, we excluded any current psychiatric illness but in consistent with a study [23] we found that patients with past psychiatric history are more likelihood to endorsing suicide thoughts. May be attributed to depressed pain patients losing hope in the medical cure, being more socially isolated; Plus thwarted belongingness and feeling of their burden on others.

\section{LIMITATIONS}

This is a cross sectional observational study so causal factors or directionality of the associations cannot be determined and does not entail a follow up strategy for the suicidal patients so future longitudinal studies need to be done. Also, the potential biases that may be introduced by the reliance on self-report data needs to be considered, Information on chronic medical illnesses or other health problems were not verified through patient records. Exclusion of SUS disorders is not verified by urine drug screen.

\section{CONCLUSIONS}

By the end of our study, we came up with the following conclusions:

CNCP patients have a high prevalence of suicidal ideation.

Our study provides valuable insight into suicidality in patients with CNCP. Identification of demographic and clinical factors associated with SI in people with $\mathrm{CNCP}$ is important for understanding of the nature of chronic pain and, more critically, for the development 
tools for early SI identification and interventions among those patient.

Declaration of interest

The authors report no conflicts of interest. The authors alone are responsible for the content and writing of the paper.

Funding information:

None declared

\section{REFERENCES}

1-World Health Organization. Mental Health: suicide data, 2017.

2-Nock, M. K., Joiner Jr, T. E., Gordon, K. H., Lloyd-Richardson, E., Prinstein, M. J. Nonsuicidal self-injury among adolescents: Diagnostic correlates and relation to suicide attempts. Psychiatry research. 2006; 144(1), 6572.

3-Pedrajas J. , Molino A. Bases Neuromédicasdel Dolor. ClínSalud. 2008; 19:277-93.

4- Castel-Bernal B., García-Bardon V. and Tornero-Molina J. EvaluaciónPsicológica en el Dolor Crónico. Reumatol Clín.2006; 2:44-9.

5-Bonica JJ.The management of Pain. Philadelphia: Lea \&Febiger. Multidisciplinary/Interdisciplinary Pin Programs. $1990 ; 197-208$.

6-Merskey H. Classification of chronic pain. Description of chronic pain syndromes and definitions of pain terms.1994; 1-213.

7-Tang N.K. and Crane C. Suicidality in chronic pain: A review of the prevalence, risk factors and psychological links. Psychol Med. 2006;36:575-86.

8- Campbell G., Darke S., Bruno R., Degenhardt L.The prevalence and correlates of chronic pain and suicidality in a nationally representative sample. Aust. N.Z. J. Psychiatry. 2015; 49 (9): 803-811.

9- World Health Organization and Mental Health. Preventing Suicide: A Global Imperative.2014; 92.

10-Carr D.R., Jacox A.K. , Chapman C.R. Acute pain management: Operative or medicalprocedures and trauma. 1992; 1:43-9.

11-Boonstra A. M., Preuper H. R. S., Balk G. A., Stewart R. E. Cut-off points for mild, moderate, and severe pain on the visual analogue scale for pain in patients with chronic musculoskeletal pain.PAIN. 2014; 155(12): 2545-2550.

12-First M. B., Spitzer R. L. Gibbon Miriam, Williams, Janet B.W. Structured Clinical
Interview for DSM-IV-TR Axis I Disorders, Research Version, Non-patient Edition. SCIDI/NP) New York: Biometrics Research; New York State Psychiatric Institute, 2002.

13-Posner K., Brown G.K., Stanley B., Brent D.A., Yershova K.V., Oquendo M.A., et al. The Columbia-suicideseverity rating scale: initial validity and internal consistency findings from three multisite studies with adolescents and adults. Am. J. Psychiatry. 2011; 168 (12): 12661277.

14-Fishbain D.A., Lewis J.E. , Gao J. The pain suicidality association: A narrative review. Pain Med. 2014;15:1835-49.

15-World Health Organization.mhGAP Intervention guide for mental, neurological and substance use disorders in non-specialized health settings, 2010.

16-Campbell G., Bruno R., Darke S., Shand F., Hall W., Farrell M. et al. Prevalence and correlates of suicidal thoughts and suicide attempts in people prescribed pharmaceutical opioids for chronic pain. The Clinical journal of pain. 2016; 32(4): 292-301

17-Wilson K. G., Kowal J., Henderson P. R., McWilliams L. A., PéloquinK.Chronic pain and the interpersonal theory of suicide. Rehabilitation psychology. 2013; 58(1): 111.

18-Van Orden K.A., Witte T.K., Cukrowicz K.C., Braithwaite S.R., Selby E.A., Joiner T.E. The interpersonal theory of suicide. Psychological Review. 2010; 117(2):575-600

19-Cheatle M.D., Wasser T., Foster C., Olugbodi A.\& Bryan J. Prevalence of suicidal ideation in patients with chronic non-cancer pain referred to a behaviorally based pain program. Pain Phys. 2014; 17 (3): 359-367.

20-Okasha, A. Focus on psychiatry in Egypt.The British Journal of Psychiatry. 2004; 185(3): 266272.

21-Smith M.T., Perlis M.L. ,Haythornthwaite J.A. Suicidal ideation in outpatients with chronic musculoskeletal pain: an exploratory study of the role of sleep-onset insomnia and pain intensity. Clin J Pain. 2004; 20: 111-8.

22-Nock M. K., Borges G., Bromet E. J., Alonso J., Angermeyer M., Beautrais A., et al. Crossnational prevalence and risk factors for suicidal 
ideation, plans and attempts. The British Journal of Psychiatry. 2008; 192(2): 98-105.

23-Fuller-Thomson E., Schrumm M., Brennenstuhl S. Migraine and despair: factors associated with depression and suicidal ideation among Canadian Migraineurs in a populationbased study. Depress. Res. Treat. 2013; 2: 401487.

24-Okifuji A., Benham B. Suicidal and self-harm behaviors in chronic pain patients. J. Appl. Behav. Res. 2011; 16 (2): 57-77.
25-Fishbain, D.A., Lewis, J.E., Bruns, D., Gao, J., Disorbio, J.M., Meyer, L. Patient predictor variables for six forms of suicidality. Eur. J. Pain. 2012; 16 (5): 706-717.

26-Racine M., Sanchez-Rodriguez E., Galan S., Tome-Pires C., Sole E., Jensen M.P., et al Factors associated with suicidal ideation in patients with chronic non-cancer pain. Pain Med. 2017; 18 (2): 283-293.

To Cite This Article Mohamed AM, Yasser MR, Rafik RA , Kariman RM. Prevalence of AND Factors Associated With Increased Suicide Risk Among Chronic Non-Cancer Pain Patients in Zagazig University Hospitals.ZUMJ 2019;25(6);950-959.DOi: 10.21608/zumj.2019.10490.11070. 